\title{
Inline Milk Lactose Concentration as Biomarker of the Health Status in Fresh Dairy Cows
}

\author{
Mindaugas Televičius 1,*, Vida Juozaitiene ${ }^{2}$, Dovilè Malašauskienè ${ }^{1}$, Ramūnas Antanaitis ${ }^{1}$, \\ Arūnas Rutkauskas ${ }^{1}$, Mingaudas Urbutis ${ }^{1}$ and Walter Baumgartner ${ }^{3}$ \\ 1 Large Animal Clinic, Veterinary Academy, Lithuanian University of Health Sciences, Tilžès 18, Kaunas, \\ Lithuania \\ 2 Department of Animal Breeding, Veterinary Academy, Lithuanian University of Health Sciences, Tilžès 18, \\ Kaunas, Lithuania \\ 3 University Clinic for Ruminants, University of Veterinary Medicine, Veterinaerplatz 1, A-1210 Vienna, \\ Austria; walter.baumgartner@vetmeduni.ac.at \\ * Correspondence: mindaugas.televicius@lsmuni.lt; +37060134279
}

Received: date; Accepted: date; Published: date

Simple Summary: In modern cow farms, the use of automatic milking systems makes it possible to detect cow diseases by analyzing AMS registered biomarkers. The aim of this study was to evaluate the relationship of an inline registered milk lactose concentration with biomarkers from AMS and some blood gas parameters and to determinate milk lactose concentration as indicator of health status in fresh dairy cows. However there is lack of information about how an inline registered lactose concentration form AMS can work as indicator of health status on fresh dairy cows. According this we hypothesized the possibility that inline registered milk lactose concentration can act as indicator for the health status in fresh dairy cows. In these studies cows with higher lactose concentration were more active and had less risk of mastitis and metabolic disorders according to fat and protein ratio $(\mathrm{F} / \mathrm{P})$. In contrary low levels of lactose can be an indicator of mastitis and metabolic disorders (Subclinical ketosis, SARA) according to F/P.

\begin{abstract}
In this study $\mathrm{pH}$, temperature of the contents of the forestomach of cows and cow activity were measured using specific smaXtec boluses manufactured for animal care. Rumination time, body weight, milk yield, milk fat/protein ratio, milk lactose, milk somatic cell count, milk electrical conductivity and conception of concentrates were registered with the help of Lely Astronaut ${ }^{\circledR}$ A3 milking robots. The following parameters were obtained: base excess in blood, partial carbon dioxide pressure, partial oxygen pressure, bicarbonate, hydrogen potential, total carbon dioxide carbon, base excess in extracellular fluid, sodium, calcium, potassium, packed cell volume, chlorides, hemoglobin concentration and lactate. According to the concentration of lactose in milk, cows were grouped into two groups: group 1 - milk lactose $<4.70 \%(n=20)$, group 2 - milk lactose $\geq$ $4.70 \%(\mathrm{n}=15)$. Data of cows were also divided by milk fat and protein ratio: $\mathrm{F} / \mathrm{P}<1.2$ (class 1 ), $\mathrm{F} / \mathrm{P}=1.2$ (class 2 ) and $\mathrm{F} / \mathrm{P}>1.2$ (class 3 ). According our results we can conclude that inline registered milk lactose concentration can be used as indicator for the health status of fresh dairy cows. Cows with higher lactose concentration $(\geq 4.70 \%)$ developed more activity $(54.47 \%)$ and had less risk of mastitis (lover milk EC, and SCC) and metabolic disorders according to F/P. Cows with higher lactose concentration showed higher glucose concentrations. Low level of lactose can be used as indicator of mastitis (milk SCC $\geq 100$ thousand/ml) and metabolic disorders according to F/P.
\end{abstract}

Keywords: milk lactose; automatic milking system; smart farming; dairy cows 


\section{Introduction}

Precision livestock farming (PLF) might be defined as "real-time monitoring technologies aimed at managing the smallest manageable production unit, otherwise known as the 'sensor-based' individual animal approach". PLF technology clearly has great potential to create added value for many stakeholders, especially as a management tool for farmers, making it possible to improve animal welfare, health, efficiency and the environmental impact [1]. One part of PLF is automatic milking systems (AMS). AMS and automatic milking rotary (AMR) parlors represent the most recent technological efforts, offering the potential for frequent milking events without depending on human labor. To date, scientific research has examined various aspects of AMS technology and its effect on milk quality, herd health, welfare, behavior, and management [2]. Automatic sensors, particularly those that monitor udder health, milk production, reproductive status, feed intake and body weight (BW) changes provide detailed information about each cow, which was not easily obtained with previous management and milking systems [3]. As a result, the health and production of individual animals can be monitored in greater detail. The milking robot is a classical PLF application and one of the types of AMS: the smallest manageable production unit in this case is one single quarter of an udder [4]. Simulation-optimization based on animal behavior was developed for robotic milking farms at the beginning of this century [5]. In robotic milking the following parameters are usually recorded: milk content, milk protein, milk fat, milk lactose, electrical conductivity and somatic cell count. It is the major bovine milk solid, and its synthesis and concentration in milk are affected mainly by udder health and the cow's energy balance and metabolism. Because this milk compound is related to several biological and physiological factors, information on milk lactose in the literature varies from chemical properties to heritability and genetic associations with health traits that may be exploited for breeding purposes [6]. Several studies have investigated the relationship of lactose content with fertility [7]. It is prescribed that lactose percentage seemed a good predictor of days to first and second postpartum ovulation [8]. Higher lactose percentage was associated with increased pregnancy rate [9] and higher lactose percentage in first 8 weeks postpartum was related to early luteal response in second-parity cows [10]. Fat to lactose ratio has been shown to be an indicator of subclinical and clinical ketosis [11] and the most informative trait for estimation of energy balance [12]. It has been reported that milk lactose concentrations decrease and SCC increases during clinical and subclinical mastitis [13]. The lactose concentration of milk could be used as an indicator of mastitis, since it clearly decreases during inflammation [13]. Monitoring the lactose levels may help in the quality control and management of farms, helping in the identification of low quality milk [14] and energy inefficiencies $[15,16]$.

\section{Materials and Methods}

\subsection{Location, animals and experimental design}

The study was conducted during the summer period from 2019.09.01 to 2019.10.01. The experiment was carried out on a dairy farm in the central region of Europe at 5600 N, 2400 E. 35 Fresh Lithuanian Black and White dairy cows ( $1-30$ days after calving) were selected according to having had two or more lactations (on average $2.9 \pm 0.13$ lactation) and being clinically healthy. The average BW of all cows was $649.14 \pm 18.92 \mathrm{~kg}$, and the level of milk SCC less than 200 thousand $/ \mathrm{ml}$. The cows were kept in a loose housing system and fed total mixed ration (TMR) twice daily, at 06:00 $\mathrm{h}$ and 18:00 h. A typical total mixed ration for high-producing, multiparous cows that consisted primarily of $50 \%$ grain concentrate mash, alfalfa hay (13 proc. protein), $10 \%$ grass silage, sugar beet pulp silage, $30 \%$ corn silage, $4 \%$ grass hay wheat straw and compound feed. To be able to motivate the cows to visit the milking robot, a total of $2 \mathrm{~kg}$ of daily concentrates were fed to them by the milking robot. The average cow production was $40.94 \pm 1.07 \mathrm{~kg}$ milk/day.

\subsection{Measurements}


The $\mathrm{pH}$ values, temperature of the contents of the forestomachs of cows and cow activity were measured using specific smaXtec boluses manufactured for animal care. SmaXtec animal care technology ${ }^{\circledR}$ enables the continuous real-time display of data such as ruminal $\mathrm{pH}$ and temperature. According to the directions of the manufacturer, the boluses were inserted into the forestomachs of the cows investigated with the help of a specific tool. The data was measured with the help of specific antennas (smaXtec animal care technology ${ }^{\circledR}$ ). For monitoring the forestomachs $\mathrm{pH}$, an indwelling and wireless data transmitting system (smaXtec animal care $\mathrm{GmbH}$, Graz, Austria) was used. The system was controlled by a microprocessor. The data ( $\mathrm{pH}$ temperature) was collected using an analogue-to-digital converter (A/D converter) and stored in an external memory chip. Due to its dimension (length: $12 \mathrm{~cm}$, width: $3.5 \mathrm{~cm}$, weight: $210 \mathrm{~g}$ ), this indwelling system can be orally administered to an adult cow and is shock-proof and resistant to rumen fluid. Calibration of the $\mathrm{pH}$-probes was performed using $\mathrm{pH} 4$ and $\mathrm{pH} 7$ buffer solutions at the beginning of the experiment. The data were read every 10 minutes daily. All data was obtained by smaXtec messenger ${ }^{\circledR}$ computer software.

The cows were milked with Lely Astronaut ${ }^{\circledR}$ A3 milking robots with free traffic. To be able to motivate the cows to visit the robot, a total of $2 \mathrm{~kg} / \mathrm{d}$ of concentrates were fed to them by the milking robot. Rumination time (RT), body weight (BW), milk yield (MY), milk fat/protein ratio (F/P), milk lactose (L), milk somatic cell count (SCC), milk electrical conductivity (EC) of all quarters of udder (front left (FL), front right (FR), rear left (RL), rear right (RR)), and conception of concentrates were registered with the help of Lely Astronaut ${ }^{\circledR}$ A3 milking robots.

Blood samples for measuring biochemical and blood gas indices were taken one time from the coccygeal vessels. Blood samples were taken at 10:00 am, prior to the start of feeding. Blood samples for measuring blood gas were collected in vacuum tubes with lithium heparin (BD Vacutainer ${ }^{\circledR}$, Great Britain) and blood samples for measuring biochemical indices were collected into vacuum test tubes without additives (BD Vacutainer ${ }^{\circledR}$, Great Britain). The collected blood samples were stored in an ice bath until all samples were taken.

Blood gas was analyzed using Epoc blood gas analyzers (EPOC, Canada). The following parameters were measured: partial oxygen pressure $\left(\mathrm{PO}_{2}\right)$, hydrogen potential $(\mathrm{pH})$, sodium $(\mathrm{Na})$, calcium (Ca), potassium (K), packed cell volume (PCV), lactate (Lac) and glucose (Glu).

For blood biochemical testing, blood samples were delivered for examination to the Large Animal Clinic's Laboratory of Clinical Tests at the Veterinary Academy of the Lithuanian University of Health Sciences, and were centrifuged for seven minutes at a speed of $3.000 \mathrm{rpm}$. The blood serum that was obtained was examined using the Hitachi 705 analyser (Hitachi, Japan), and DiaSys reagents (Diagnostic Systems $\mathrm{GmbH}$, Germany), determining the concentrations of blood serum albumin (Alb), urea (Urea), iron (Fe), alanine aminotransferase (ALT), aspartate aminotransferase (AST).

The research was performed according to the provisions of the Law of the Republic of Lithuania No. 8-500 on Protection, Keeping and Use of Animals, dated 06/11/1997 (Valstybès žinios (official gazette) No. 108 dated 28/11/1997) and orders of the State Veterinary Service of the Republic of Lithuania on Breeding, Care, Transportation of Laboratory Animals (No. 4-361, dated 31/12/1998) and Use of Laboratory Animals for Scientific Tests (No. 4-16, dated 18/01/1999). The study's approval number was PK016965.

According to the concentration of lactose in milk, cows were grouped into two groups: group 1 - milk lactose $<4.70 \%(n=20)$, group 2 - milk lactose $\geq 4.70 \%(n=15)$.

Data of cows were also grouped by milk fat and protein ratio: $\mathrm{F} / \mathrm{P}<1.2$ (class 1), $\mathrm{F} / \mathrm{P}=1.2$ (class 2 ) and $\mathrm{F} / \mathrm{P}>1.2$ (class 3 ).

\subsection{Data analysis and statistics}

The statistical analysis of data was performed using the SPSS 25.0 (SPSS Inc., Chicago, IL, USA) program package. Mean values recorded by milking robots (RT; BW; MY; F/P; L; SCC; EC) average from 30-day period were used in the study. Using descriptive statistics, normal distributions were assessed using Kolmogorov-Smirnov test. The results were expressed as the mean \pm standard error 
of the mean $(\mathrm{M} \pm \mathrm{SE})$. Differences in mean values of normal distributed variables were analyzed using Student's t-test. A probability of less than 0.05 was considered reliable ( $P$-value $<0.05$ ).

The Pearson correlation ( $\mathrm{r}$ ) was calculated to define the linear relationship of milk lactose with forestomach parameters like $\mathrm{pH}$ and temperature $(\mathrm{T})$ as well as biomarkers from AMS: milk yield (MY), milk fat, milk protein and milk fat and protein ratio (F/P), electrical conductivity of milk (EC) at udder quarters level (left front, right front, left rear, right rear), activity of cows, rumination time (RT) and consumption of concentrates (CC). The relationship between the SCC class of milk (SCC $<100$ thousand/ml or $S C C \geq 100$ thousand/ml) and a group of cows by milk lactose level was evaluated using Pearson's $\chi 2$ test.

A binary logistic regression method was performed using milk lactose level as a dependent variable to predict the relationship with SCC and F/P levels in cow's milk. Estimates were used to calculate odds ratios (ORs).

\section{Results}

The average productivity of cows was $40.94 \pm 1.07 \mathrm{~kg}$ milk, milk fat concentration $-4.46 \pm 0.106 \%$, milk protein - $3.66 \pm 0.034 \%$, milk lactose $-4.65 \pm 0.009 \%$, milk fat and protein ratio $-1.22 \pm 0.029$.

\subsection{The relationship between the level of milk lactose and milk characteristics of cows}

The lactose content in milk of cows was statistically significantly positively related to the content of milk protein $(\mathrm{r}=0.436 ; \mathrm{P}<0.05)$ and negatively correlated with EC of milk $(\mathrm{r}=-0.695$ 0.993; $\mathrm{P}<0.001$ ). The correlations of milk lactose with $\mathrm{MY}$, milk fat, and $\mathrm{F} / \mathrm{P}$ were slightly positive (0.091-0.170), but statistically unreliable (Fig. 1).

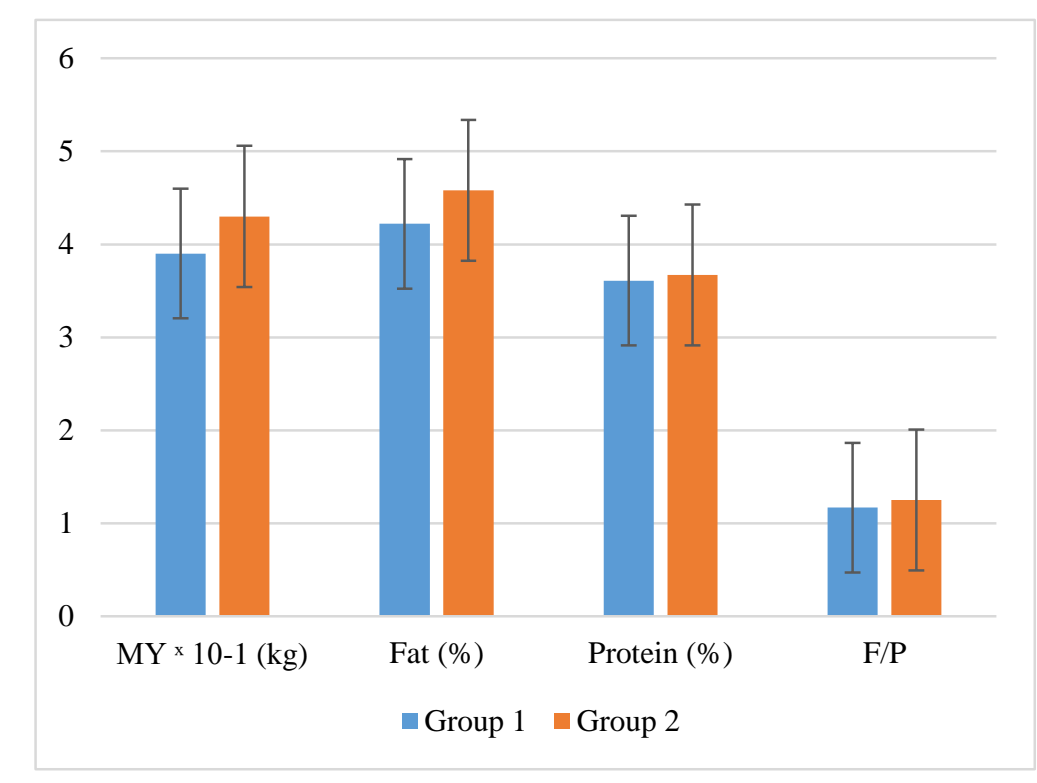

Figure 1. Milk characteristics of cows by milk lactose level.

Productivity in the cows of the $1^{\text {st }}$ group was $10.26 \%$ lower and the milk fat and protein ratio was $9.59 \%$ lower. In the milk of cows of the $2^{\text {nd }}$ group there was less milk fat and protein $(1.09$ and 1.02 times), but the differences between the average for these indicators of milk were not statistically significant.

The electrical conductivity level of milk in group 1 was higher in all quarters of the udder compared to cows in group 2 (Fig. 2) from 5.66\% (rear right quarter) to 9.72\% (front right quarter), and differences between groups in EC means of milk in all udder quarters were statistically significant $(\mathrm{P}<0.001)$. 


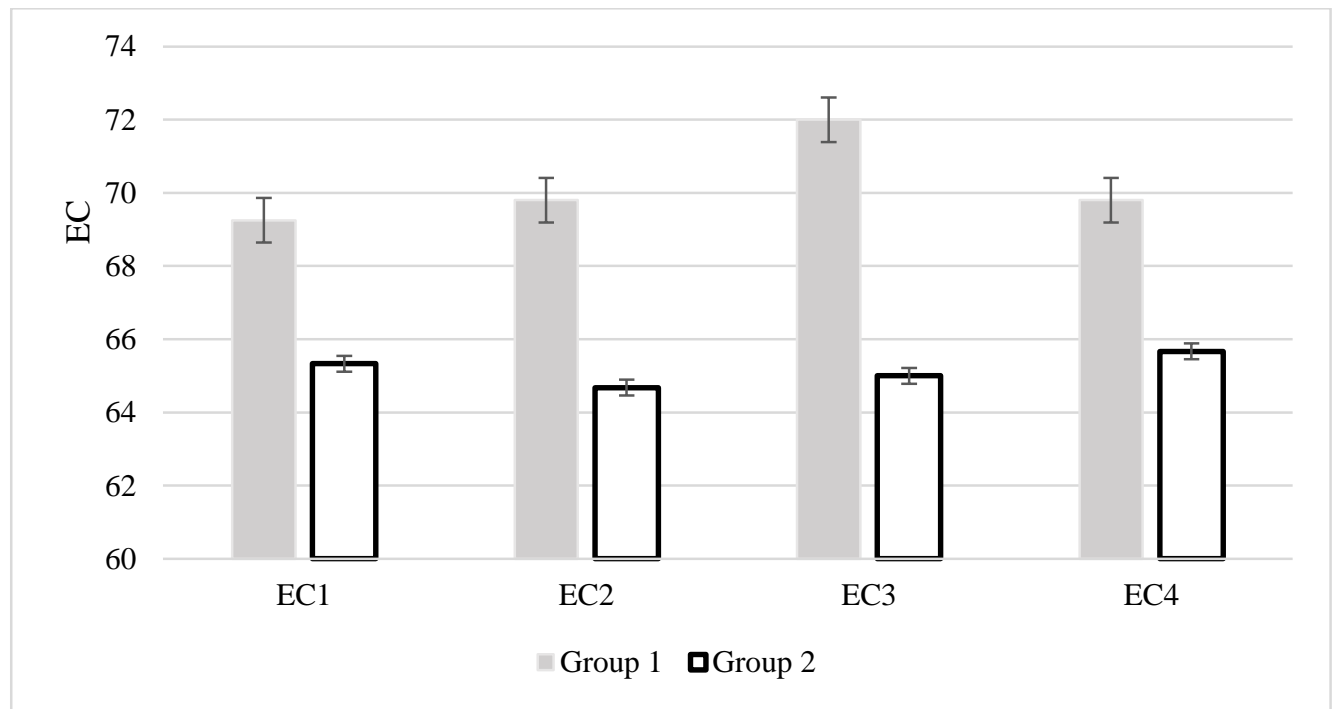

Figure 2. Electrical conductivity of cows milk at the level of udder quarters $(\mu \mathrm{S} / \mathrm{cm})$ : EC1 - rear right, EC2 - rear left, EC3 - front right, EC4 - front left.

A statistically significant relationship between group of cows and level of SCC in milk has been estimated $(\mathrm{P}<0.001)$. In group 1 we found $59.52 \%$ more cows with milk SCC $\geq 100$ thousand $/ \mathrm{ml}$ (Table 1). A binary regression analysis showed that milk lactose $<4.70 \%$ statistically reliable increased the risk of subclinical mastitis in dairy cows $(\mathrm{OR}=15.583, \mathrm{P}=0.001)$.

Table 1. Relationship of milk SCC with milk lactose level.

\begin{tabular}{ccc}
\hline \multirow{2}{*}{ Milk SCC level (thousand/ml) } & \multicolumn{2}{c}{ Cows \% } \\
\cline { 2 - 3 } & Group 1 & Group 2 \\
\hline SCC $<100$ & 21.43 & 80.95 \\
SCC $\geq 100$ & 78.57 & 19.05 \\
\hline$\chi 2=12.153, \mathrm{DF}=1, \mathrm{P}<0.001$ \\
\hline
\end{tabular}

Cows with lactose $<4.70 \%$ in milk were also found to be more prone to the risk of subclinical acidosis or ketosis $(\mathrm{OR}=2.00, \mathrm{P}=0.376)$. The cows of the first group with SARA signs accounted for $33.33 \%$ more animals in the mentioned SARA class $(\mathrm{F} / \mathrm{P}<1.2)$ than the cows of the second group. We also found that in $\mathrm{F} / \mathrm{P}>1.2$ class there were $9.09 \%$ more cows of the first group, and in this class with signs of subclinical ketosis, the total number of cows of the second group was $54.55 \%$ (Fig 3).

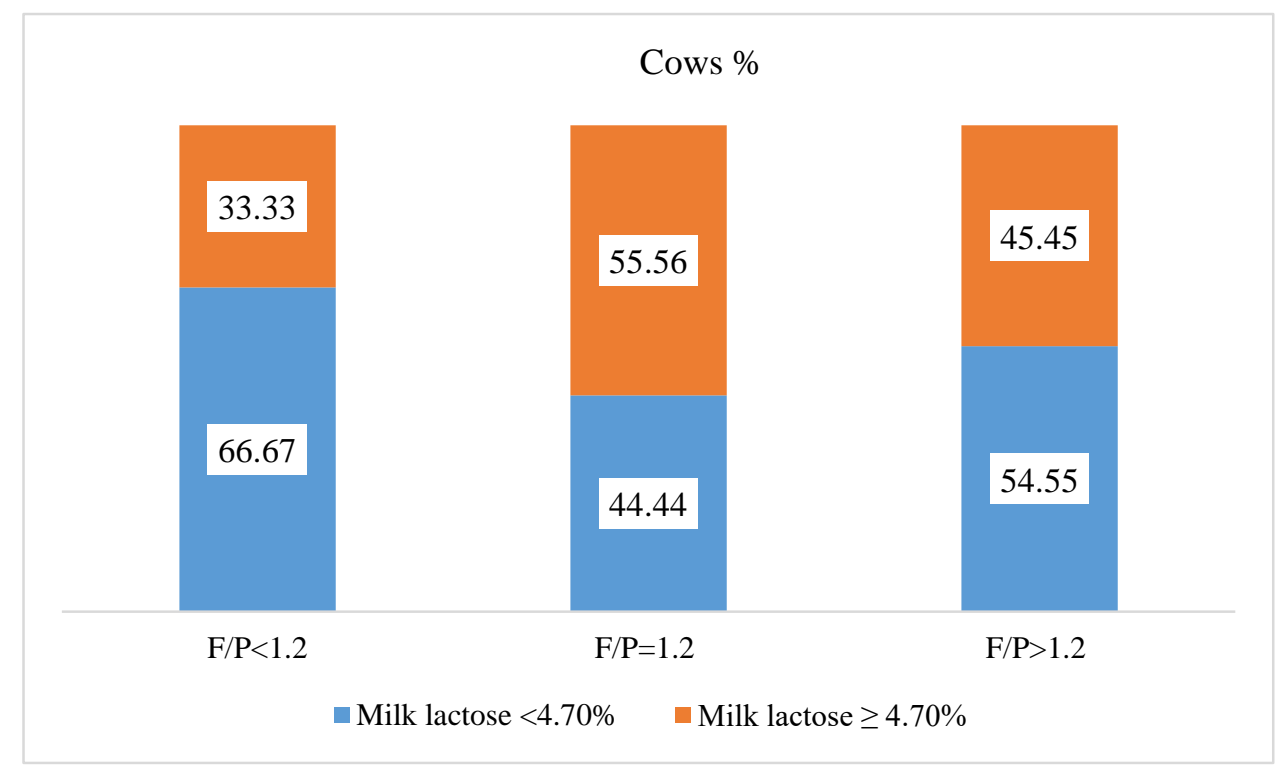


Figure 3. Relationship of milk fat to protein ratio $(\mathrm{F} / \mathrm{P})$ with milk lactose level.

From our investigation, $50 \%$ of cows in the first group had a risk of mastitis (milk SCC $\geq 100$ thousand/ml) and at the same time - a risk of metabolic disorders according to F/P. None of the cows in the second group had this risk of both diseases.

\subsection{The relationship between the level of milk lactose and biomarkers from AMS}

The average forestomach $\mathrm{pH}$ of all cows was $6.42 \pm 0.002$, forestomach temperature $-38.83 \pm 0.041$ ${ }^{\circ} \mathrm{C}$, activity - $9.913 \pm 0.656 \mathrm{steps} /$ hour, RT- $441.14 \pm 12.58 \mathrm{~min} / \mathrm{d}$.

Forestomach $\mathrm{pH}$ in group 2 was $2.52 \%$ higher $(\mathrm{P}<0.001)$, level of activity $-54.47 \%$ higher $(\mathrm{P}<0.001)$, rumination time $-9.86 \%$ longer compared to cows of group 1 (Table 2 ).

Table 2. Indicators of forestomach, RT, activity of cows and their relationship with milk lactose.

\begin{tabular}{cccccc}
\hline $\begin{array}{c}\text { Group of } \\
\text { cows }\end{array}$ & Statistic & $\begin{array}{c}\text { Forestomach } \\
\mathbf{p H}\end{array}$ & $\begin{array}{c}\text { Forestomach } \\
\mathbf{T}^{\circ} \mathbf{C}\end{array}$ & $\begin{array}{c}\mathbf{R T} \text {, } \\
\mathbf{m i n} / \mathbf{d} .\end{array}$ & $\begin{array}{c}\text { Activity of cows, } \\
\text { steps/hour }\end{array}$ \\
\hline \multirow{2}{*}{1} & $\mathrm{M}$ & 6.34 & 38.84 & 467.40 & 8.39 \\
& $\mathrm{SE}$ & 0.291 & 0.113 & 34.230 & 1.006 \\
\cline { 2 - 6 } 2 & $\mathrm{M}$ & $6.50^{* * *}$ & 38.82 & 421.33 & $12.96^{* * *}$ \\
& $\mathrm{SE}$ & 0.302 & 0.263 & 49.600 & 4.186 \\
\hline \multicolumn{2}{c}{ Correlation } & $0.762^{* *}$ & 0.130 & -0.296 & $0.751^{* *}$ \\
\hline
\end{tabular}

${ }^{*} \mathrm{P}<0.05,{ }^{* *} \mathrm{P}<0.01,{ }^{* * \mathrm{P}<0.005}$

Milk lactose highly positively related with forestomach $\mathrm{pH}$ and activity of cows $(\mathrm{P}<0.01)$.

\subsection{The relationship between the level of milk lactose and blood indicators of cows}

In group 2 higher concentrations of $\mathrm{K}, \mathrm{Fe}, \mathrm{Lac}, \mathrm{Urea}, \mathrm{ALB}$, higher activities of ALT and AST, higher levels of $\mathrm{pO}_{2}$, urea, $\mathrm{pH}, \mathrm{PCV}$ and lower $\mathrm{Na}$ as well as $\mathrm{Ca}$ were calculated. In group 2 Glu was statistically higher $(\mathrm{P}<0.05)$.

As the data in table 3 show, milk lactose was negatively correlated with $\mathrm{Na}$ in the blood. Statistically significant positive correlations of lactose were calculated with blood $\mathrm{K}, \mathrm{Fe}, \mathrm{ALB}, \mathrm{ALT}$, AST, urea $(\mathrm{P}<0.01)$ and glucose $(\mathrm{P}<0.05)$.

Table 3. Blood indicators and their relationship with milk lactose.

\begin{tabular}{cccccc}
\hline \multirow{2}{*}{ Blood indicators } & \multicolumn{2}{c}{ Group 1 } & \multicolumn{2}{c}{ Group 2 } & \multirow{2}{*}{ Correlation } \\
\cline { 2 - 5 } & $\mathbf{M}$ & SE & M & SE & \\
\hline $\mathrm{Na}(\mathrm{mmol} / \mathrm{l})$ & 137.80 & 1.020 & 137.00 & 1.155 & $-0.505^{* *}$ \\
$\mathrm{~K}(\mathrm{mmol} / \mathrm{l})$ & 4.00 & 0.148 & 4.33 & 0.120 & $0.486^{* *}$ \\
$\mathrm{Ca}(\mathrm{mmol} / \mathrm{l})$ & 1.16 & 0.024 & 1.127 & 0.047 & 0.011 \\
$\mathrm{Fe}(\mu \mathrm{mol} / \mathrm{l})$ & 23.60 & 2.440 & 31.53 & 6.14 & $0.585^{* *}$ \\
$\mathrm{Glu}(\mathrm{mmol} / \mathrm{l})$ & 2.70 & 0.145 & $2.867^{*}$ & 0.233 & $0.422^{*}$ \\
$\mathrm{Lac}(\mathrm{mmol} / \mathrm{l})$ & 1.80 & 0.691 & 1.96 & 0.306 & 0.050 \\
$\mathrm{ALB}(\mathrm{g} / \mathrm{l})$ & 35.41 & 0.742 & 37.98 & 1.173 & $0.790^{* *}$ \\
$\mathrm{ALT}(\mathrm{TV} / \mathrm{l})$ & 29.20 & 2.035 & 32.33 & 4.333 & $0.673^{* *}$ \\
$\mathrm{AST}(\mathrm{TV} / \mathrm{l})$ & 92.00 & 13.012 & 102.67 & 23.695 & $0.578^{* *}$ \\
$\mathrm{Urea}(\mathrm{mmol} / \mathrm{l})$ & 5.89 & 0.278 & 6.15 & 0.111 & $0.459^{* *}$ \\
$\mathrm{pH}$ & 7.42 & 0.030 & 7.421 & 0.029 & -0.256 \\
$\mathrm{pO} 2 \mathrm{mmHg}$ & 79.50 & 29.522 & 45.500 & 15.432 & -0.263 \\
$\mathrm{PCV}($ fraction $)$ & 24.00 & 1.304 & 25.6 & 2.028 & 0.279 \\
\hline
\end{tabular}

${ }^{*} \mathrm{P}<0.05,{ }^{* *} \mathrm{P}<0.01$

\section{Discussion}


In current study we hypothesized the possibility that inline registered milk lactose concentration can be an indicator for the health status in fresh dairy cows. Lactose, EC and their combination were the most accurate variables to detect mastitis on dairy farms equipped with in-line sensors. Clinical (CM) and subclinical (SCM) mastitis influence the quantity and quality of milk and therefore they are of major economic concern for the dairy industry. Early detection of mastitis (especially SCM) can improve animal welfare and the quality of milk production, and increase economic gains. According the current study, we found that with increase of the concentration of lactose, possibility of mastitis decreases (lower milk EC, and SCC). The concentration of lactose has been reported to be influenced by high milk somatic cell counts (SCC). Berglund et al. [17] observed that an increase from 31,000 to 450,000 somatic cells mL-1 reduced the lactose content from 4.86 to $4.69 \%$. This was due to a reduction in lactose secretion [18] and loss of lactose to the bloodstream because of increased permeability of the tight junction [19]. Substantial reductions in the lactose levels were correlated with the increase in SCC, as observed in the factor analysis, in which the lactose content had contrary relationship with SCC [20]. Phenotypic and genetic correlations of -0.774 and -0.227 between the lactose content and SCS were estimated by Lindmark-Månsson et al. [21] and Miglior et al. [22], respectively. The increase in SCC, which is an indicator of clinical and subclinical mastitis, decreases the lactose levels in milk, due to changes in the homeostasis of mammary glands [23], increasing the blood concentration of lactose [24]. According Leitner et al. [25] blood lactose is increased in cases of subclinical mastitis and, in a more pronounced way, in clinical mastitis. However, in subclinical mastitis the integrity of tight junctions is partly maintained. Leitner et al. [18] argued that the lower concentration of lactose in cows with intramammary infection was also related to the reduction in the secretion of lactose by further conversion of plasminogen to plasmin. Ebrahimie et al. [26] found that milk lactose concentrations decrease and SCC increases during clinical and subclinical mastitis. Few studies by other scientists say that lactose, SCC and milk electrical conductivity has been widely reported to be one of the most informative traits for mastitis diagnosis [27, 28]. According to a study conducted by Costa et al. [29], mastitis genetically correlated with milk lactose yield.

The results in this study indicate that cows with a low lactose $(<4,70 \%)$ and $\mathrm{F} / \mathrm{P}$ ratio in the interval $(<1 ;>2)$ in milk reliable increased the risk of metabolic disorders (subclinical ketosis and acidosis). Toni et al. [30] also found that the F/P interval $(<1 ;>2)$ in milk is a valuable indicator of lipo-mobilization and the negative energy balance in postpartum cows. According Ganter et al. [31] due to a negative energy balance at the beginning of lactation, the milk fat content tends to increase, while the milk protein content tends to decrease, which makes the $\mathrm{F} / \mathrm{P}$ ratio a good indicator in metabolic disorder detection.

We found, that cows with higher lactose concentration, were more active (54.47\%), and had less risk of subclinical acidosis (SARA) $(2.52 \%$ higher forestomach $\mathrm{pH}$, and $9.86 \%$ longer rumination time). Antanaitis et al. [32] reported that cows with acidosis showed lower activity than healthy cows. According Church [33] increased time ruminating enhances the saliva production. Saliva contains inorganic buffers, that contribute to the neutralization of the organic acids produced during fermentation in the rumen $[33,34]$. Corresponding few studies, the rumen fluid $\mathrm{pH}$ that defines SARA is still a controversial issue [35], however in previous studies [36, 37, 38] a decrease in rumen $\mathrm{pH}$ below 6 indicates the occurrence of SARA. Agreeing Antanaitis et al. [39] cows affected by SARA have been shown to have reduced rumination time.

According blood biochemical parameters relation with lactose concentration, we found that cows with higher lactose concentration have higher glucose concentration. Our results are in agreement with the results of studies [40,15], which state that as blood glucose levels increase, milk lactose levels also increase. Mammary tissue of dairy cows extracts $\sim 20 \%$ of glucose from blood [15, 29]. According to Costa et al. [29] milk lactose is the main carbohydrate in mammals' milk, and it is responsible for the osmotic equilibrium between blood and alveolar lumen in the mammary gland. The differences between the seasons affect the food intake, metabolism of nutrients, and therefore, the availability of glucose, which is the substrate for the synthesis of lactose [15, 16], with 
consequently impacts the milk yield and composition. The supply of glucose for lactose synthesis increases dramatically in the mammary gland of lactating animals [41].

In previous studies, we have determined the heritability coefficient for milk lactose $\left(h^{2}=0.279\right)$ and a negative genetic correlation $\left(\mathrm{r}_{\mathrm{g}}=-0.43 ; \mathrm{p}<0.01\right)$ with milk somatic cells [42]. Data from this study also confirmed that higher levels of lactose in cows' milk are associated with a lower risk of mastitis.

Lactose is a major osmotic component of milk and is a major driver of water secretion into milk. Thus, a lower lactose content results in smaller volume of milk produced [28].

\section{Conclusions}

According our results we can conclude that inline registered milk lactose concentration can be an indicator for the health status in fresh dairy cows. Cows with a higher lactose concentration $(\geq$ $4.70 \%$ ) were more active (54.47\%) and had less risk of mastitis (lover milk EC and SCC) and metabolic disorders according to F/P. Cows with higher lactose concentrations show higher glucose concentrations. Low level of lactose can be an indicator of mastitis (milk SCC $\geq 100$ thousand/ml) and metabolic disorders (Subclinical ketosis, SARA) according to F/P.

Author Contributions: M.T.: supervision of the whole study; V.J.: software and algorithm development, design and setup of field experiments, data collection, and analysis; D.M.: setup of the field experiment and data collection, selection, and management of the experimental group of animals; R.A.: research consultancy; A.R.: design of field experiment and data collection, data collection, and analysis; M.U.: design of field experiment and data collection, data collection, and analysis; and W.B.: intensive support in processing of data in the manuscript. The manuscript was written by M.T. and revised by all co-authors. All authors have read and agreed to the published version of the manuscript.

Funding: This research received no external funding.

Conflicts of Interest: The authors declare no conflict of interest

\section{References}

1. Berckmans, D. Precision livestock farming technologies for welfare management in intensive livestock systems. Rev. sci. tech. Off. int. Epiz. 2014, 33, 189-196.

2. Jacobs, J.A.; Siegford, J.M. Invited review: The impact of automatic milking systems on dairy cow management, behavior, health, and welfare. J. Dairy Sci. 2012, 95, 5, 2227-2247.

3. Spahr, S.L.; Maltz, E. Herd management for robot milk-ing. Comp. Electron. Agric. 1997, 17: 53-62.

4. Halachmi, I.; Guarino, M. Editorial: Precision livestock farming: a 'per animal' approach using advanced monitoring technologies. Anim. Consortc. 2016, 10, 1482-1483.

5. Halachmi, I. Designing the automatic milking farm in a hot climate. J. Dairy Sci. 2004, 87, 764-775.

6. Costa, A.; Egger-Danner, C.; Mészáros, G.; Fuerst, C.; Penasa, M.; Sölkner, J.; Fuerst-Waltl, B. Genetic associations of lactose and its ratios to other milk solids with health traits in Austrian Fleckvieh cows. J. Dairy Sci. 2019, 102, 4238-4248.

7. Miglior, F.; Sewalem, A.; Jamrozik, J.; Lefebvre, D.M.; Moore, R.K. Analysis of Milk Urea Nitrogen and Lactose and Their Effect on Longevity in Canadian Dairy Cattle. J. Dairy Sci. 2006 89, 4886-4894.

8. Francisco, C.C.; Spicer, L.J.; Payton, M.E. Predicting cholesterol, progesterone, and days to ovulation using postpartum metabolic and endocrine measures. J. Dairy Sci. 2003, 86, 2852-2863.

9. Buckley, F.; O’Sullivan, K.; Mee, J.F.; Evans, R.D.; Dillon, P. Relationships among milk yield, body condition, cow weight, and reproduction in spring-calved Holstein-Friesians. J. Dairy Sci. 2003, 86, 2308-2319.

10. Reksen, O.; Havrevoll, Ø.; Gro ‘hn, Y.T.; Bolstad, T.; Waldmann, A.; Ropstad, E. Relationships among body condition score, milk constituents, and postpartum luteal function in Norwegian dairy cows. J. Dairy Sci. 2002, 85, 1406-1415.

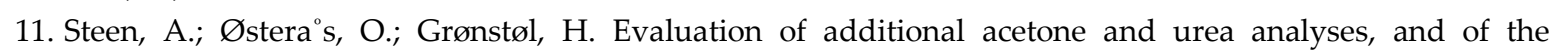
fat-lactose-quotient in cow milk samples in the herd recording system in Norway. J. Vet. Med. A. 1996, 43, 181-191.

12. Reist, M.; Erdin, D.; von Euw, D.; Tschuemperlin, K.; Leuenberger, H.; Chilliard, Y.; Hammon, H.M.; Morel, C.; Philipona, C.; Zbinden, Y.; Kuenzi, N; Blum, J.W. Estimation of energy balance at the individual and herd level using blood and milk traits in high-yielding dairy cows. J. Dairy Sci. 2002, 85, 3314-3327. 
13. Pyöräla, S. Indicators of inflammation in the diagnosis of mastitis. Vet. Res. 2003, 565-578.

14. Leitner, G.; Lavi, Y.; Merin, U.; Lemberskiy-Kuzin, L.; Katz, G. Online evaluation of milk quality according to coagulation properties for its optimal distribution for industrial applications. J. Dairy Sci. 2011, 94, 2923-2932.

15. Rigout, S.; Lemosquet, S.; van Eys, J.E.; Blum, J.W.; Rulquin, H. Duodenal glucose increases glucose fluxes and lactose synthesis in grass silage-fed dairy cows. J. Dairy Sci. 2002, 85, 595-606.

16. Qiao, F.; Trout, D.R.; Xiao, C.; Cant, J.P. Kinetics of glucose transport and sequestration in lactating bovine mammary glands measured in vivo with a paired indicator/nutrient dilution technique. J. Applied Phys. 2005, 99, 799-806.

17. Berglund, I.; Pettersson, G.; Ostensson, K.; Svennersten-Sjaunja, K. Quarter milking for improved detection of increased SCC. Rep. Dom. Anim. Malden. 2007, 427-432.

18. Leitner, G.; Merin, U.; Lavi, Y.; Egber, A.; Silanikove, N. Aetiology of intramammary infection and its effect on milk composition in goat flocks. J. Dairy Res. 2007, 74, 186-193.

19. Moussaoui, F.; Vangroenweghe, F.; Haddadi, K.; Le Roux, Y.; Laurent, F.; Duchateau, L.; Burvenich, C. Proteolysis in milk during experimental Escherichia coli mastitis. J. Dairy Sci. 2004, 87, 2923-2931.

20. Alessio, M.; Regina, D.; André, T.N.; Pedro, V.J.; Ildemar, B.P.; José, M.D.; Aline, K.D.; Claudineli, G.S. Multivariate analysis of lactose content in milk of Holstein and Jersey cows. Ciênci. Agrár. 2016, 37, 2641-2652.

21. Lindmark-Mansson, H.; Branning, C.; Alden, G.; Paulsson, M. Relationship between somatic cell count individual leukocyte populations and milk components in bovine udder quarter milk. Inter. Dairy J.2006, 16, 717- 727.

22. Miglior, F.; Sewalem, A.; Jamprozik, J.; Bohmanova, J.; Lefebvre, D.M.; Moore, R.K. Genetic analysis of milk urea nitrogen and lactose and their relationships with other production traits in Canadian Holstein cattle. J. Dairy Sci. 2007, 90, 2468-2479.

23. Pessora, R.B.; Blagitz, M.G.; Batista, C.F.; Santos, B.P.; Parra, A.C.; Souza, F.N.; Della Libera, A.M.M.P. Avaliação da apoptose de leucócitos polimorfonucleares $\mathrm{CH} 138+$ em leite bovino de alta e baixa contagem de células somáticas dados preliminares. Arquivo Brasileiro Medicina Veterinária e Zootecnia, Belo Horizonte, 2012, 64, 3, 533-539.

24. Ben Chedly, H.; Lacasse, P.; Marnet, P.; Wiart-Letort, S.; Finot, L.; Boutinaud, M. Cell junction disruption after $36 \mathrm{~h}$ milk accumulation was associated with changes in mammary secretory tissue activity and dynamics in lactating dairy goats. J. of Phys. and Pharm.: An Official Journal of the Polish Physiological Society, 2009, 60, 3, 105-111.

25. Leitner, G.; Chaffer, M.; Shamay, A.; Shapiro, F.; Merin, U.; Ezra, E.; Saran, A.; Silanikove, N. Changes in milk composition as affected by subclinical mastitis in sheep. J. Dairy Sci. 2004, 87, 46-52.

26. Ebrahimie, E.; Ebrahimi, F.; Ebrahimi, M.; Tomlinson, T.; Petrovski, K.R. A large-scale study of indicators of sub-clinical mastitis in dairy cattle by attribute weighting analysis of milk composition features: highlighting the predictive power of lactose and electrical conductivity. J. Dairy Res. 2018, 85, 193-200.

27. Geary, U.; Lopez-Villalobos, N.; O’Brien, B; Garrick, D.J.; Shalloo, L. Estimating the impact of somatic cell count on the value of milk utilising parameters obtained from the published literature. J. Dairy Res. 2014, 81, 223-232.

28. Vilas Boas, D.F.; Vercesi Filho, A.E.; Pereira, M.A.; Roma Junior, L.C.; El Faro, L. Association between electrical conductivity and milk production traits in Dairy Gyr cows. J. Applied Anim. Res. 2017, 45, 227233.

29. Costa, A.; Lopez-Villalobos, N.; Sneddon, N.W.; Shalloo,L.; Franzoi, M.; De Marchi, M.; Penasa, M. Invited review: Milk lactose-Current status and future challenges in dairy cattle. J. Dairy Sci. 2019, 102, 5883-5898.

30. Toni, F.; Vincenti, L.; Grigoletto, L.; Ricci, A.; Schukken, Y. H. Early lactation ratio of fat and protein percentage in milk is associated with health, milk production, and survival. J. Dairy Sci. 2011, 94, 1772-1783.

31. Gantner, V.; Bobic, T.; Potocnik, K. Prevalence of metabolic disorders and effect on subsequent daily milk quantity and quality in Holstein cows. Arch. Anim. Breed. 2016, 59, 381-386.

32. Antanaitis, R.; Žilaitis, V.; Kučinskas, K.; Juozaitienė, V.; Leonauskaitė, K. Changes in cow activity, milk yield, and milk conductivity before clinical diagnosis of ketosis, and acidosis. Vet. Med. Zoot. 2015, 1392-2130.

33. Church, D.C. Salivary function and production. The Ruminant Animal, Digestive Physiology and Nutrition, Prentice Hall, Englewood Cliffs, NJ. 1988, 117-124. 
34. Plaiziera, J.C.; Krausea, D.O.; Gozhob, G.N.; McBridec, B.W. Subacute ruminal acidosis in dairy cows: The physiological causes, incidence and consequences. Vet. J. 2008, 176, 21-31.

35. Gozho, G.N.; Plaizier, J.C.; Krause, D.O.; Kennedy A.D.; Wittenberg, K.M. Subacute Ruminal Acidosis Induces Ruminal Lipopolysaccharide Endotoxin Release and Triggers an Inflammatory Response. J. Dairy Sci. 2005, 88, 1399-1403.

36. Hibbard, B.; Peters, J.P.; Chester, S.T.; Robinson, J.A.; Kotarski, S.; Croom, W.J.; Hagler, W.M. The effect of slaframine on salivary output and subacute and acute acidosis in growing beef steers. J. Anim. Sci. 1995, 73, 516-525.

37. Kriehbiel, C.R.; Britton, R.A.; Harmon, D.L.; Wester, T.J.; Stock, R.A. The effects of ruminal acidosis on volatile fatty acid absorption and plasma activities of pancreatic enzymes in lambs. J. Anim. Sci. 1995, 73, 3111-3121.

38. Beauchemin, K.A.; Yang, W.Z.; Rode, L.M. Effects of barley grain processing on the site and extent of digestion in beef. J. Anim. Sci. 2001, 79: 1925-1936.

39. Antanaitis, R.; Juozaitienè, V.; Malašauskienė, D.; Televičius, M. Can rumination time and some blood biochemical parameters be used as biomarkers for the diagnosis of subclinical acidosis and subclinical ketosis. Vet. Anim. Sci. 2019, 18, 2451-943.

40. Hurtaud, C.; Rulquin, H.; Verite, R. Effects of Graded Duodenal Infusions of Glucoseon Yield and Composition of Milk from Dairy Cows.1. Diets Based on Corn Silage. J. Dairy Sci. 1998, 81, 3239-32473239.

41. Osorio, S.J.; Lohakare, J.; Bionaz, M. Biosynthesis of milk fat, protein, and lactose: roles of transcriptional and posttranscriptional regulation. Physiol. Genomics. 2016, 48, 231-256.

42. Shimkiene, A.; Juozaitiene, V.; Juozaitis, A.; Shimkus, A.; Zilaitis, V.; Urbonavicius, A. Relationship between lactose content in cow's milk with selection attributes and heritability. Veterinarija ir zootechnika (Vet Med Zoot). 2009, 45 (67), 81-86.

(C) 2020 by the authors. Submitted for possible open access publication under the terms and conditions of the Creative Commons Attribution (CC BY) license (http://creativecommons.org/licenses/by/4.0/). 